\title{
SEEING IS BELIEVING! LIVE CONFOCAL IMAGING OF MICROVASCULAR NETWORKS IN SITU: MORPHOLOGY, $\mathrm{Ca}^{2+}$ SIGNALLING AND TONE
}

\author{
T. BURDYGA, L. BORYSOVA
}

\author{
Department of Cellular and Molecular Physiology, Institute of Translational Medicine, \\ University of Liverpool, Crown Street, Liverpool, L69 3BX, UK
}

2- and 3-dimensional confocal imaging of Fluo-4 loaded ureteric microvesells in situ allowed us to demonstrate distinct morphology, $\mathrm{Ca}^{2+}$ signalling and contractility in myocytes of arcade arterioles and pericytes of arcade venules. In myocytes and pericytes, $\mathrm{Ca}^{2+}$ signals arise exclusively from $\mathrm{Ca}^{2+}$ release from the sarcoplasmic reticulum through inositol 1,4,5-trisphosphate receptors. $\mathrm{Ca}^{2+}$ transients in pericytes are less oscillatory, slower and longer-lasting than those in myocytes. The data obtained suggest differences in the mechanisms controlling local blood flow in precapillary arterioles and postcapillary venules.

Key words: Ca ${ }^{2+}$ signalling, myocytes, pericytes, microvascular networks, confocal microscopy.

\section{Confocal imaging of} microvascular networks in situ

Imaging of microvascular networks in situ is a dream of any vascular physiologist and has always been technically challenging until recently when techniques of live imaging of intact microvessels in intact tissue [1, 2] or tissue slices [3] have been developed. A range of fluorescent, $\mathrm{Ca}^{2+}$-sensitive dyes along with a chemical strategy allowing them to be easily introduced into intact cells have been developed [4]. The most successful of these compounds for confocal imaging were non-ratiometric $\mathrm{Ca}^{2+}$ sensitive indicators fluo-3 and fluo-4. The development of confocal microscopy and high-speed sensitive CCD-based cameras made possible to visualise local and global changes in $\left[\mathrm{Ca}^{2+}\right]_{\mathrm{i}}$ within individual cells. Confocal microscopy uses laser excitation of cell fluorescence with a pinholes, which excludes out-of-focus light. This allows to obtain clear optical sections from much thicker tissues samples. Seeing live images of the tiniest blood vessels in the tissue is an absolutely amazing and exciting experience and provides unique opportunity to investigate $\mathrm{Ca}^{2+}$ signalling and vasomotor responses in intact microvessels in their natural environment in an accessible and stimulating way. The invisible becomes visible, revealing exceptional beauty of morphology and exciting heterogeneity of $\mathrm{Ca}^{2+}$ signalling in cellular and subcellular levels in myocytes, pericytes and endothelial cells of microvesels. It is well exemplified by comparing morphology and $\mathrm{Ca}^{2+}$ signalling of precapillary arcade arterioles and postcapillary arcade venules, which parallel each other but belong to different parts of microvascular networks. Traditionally precapillary arterioles are seen as small resistance microvessels, involved in control of tissue blood flow, while postcapillary venules are known to play a key role in control of extravasation of white blood cells in response to infection or inflammation [5]. Close proximity of these anatomically and physiologically different microvessels gives a unique opportunity to compare their morphology, $\mathrm{Ca}^{2+}$ signalling and vasomotor responses to central and local vasoconstrictors and vasodilators under identical experimental conditions, which will be briefly discussed in the current paper.

\section{Morphology of the arcade} arterioles and venules

Figure 1 A shows confocal images of fluo- 4 loaded arteriole/venule pair $\left(\lambda_{\text {ex }}=488 \mathrm{nM}\right.$, $\lambda_{\text {em }}=510 \mathrm{nM}$ ), obtained by the method developed in our laboratory using Nipkow disc based confocal imaging system (For details see [1, 2]). Figure $1 \mathrm{~A}$ shows distinct morphology of arterioles and venules. The wall of the arteriole has a single layer of closely opposed, circularly orientated myocytes (Fig. 1Ai). Smooth muscle cells are spindle shaped and depending on the diameter of the arteriole can make up to 2 full turns around endothelium [2]. The postcapillary arcade venules are surrounded by spidery pericytes, with stellate cell bodies giving slender cell projections (Fig. 1Aii). These projections appear to be randomly oriented with respect to the vessel axis, and overlap and/or attach to each other, forming a complicated and dense (Fig. 1Aii). The processes interconnect with each other leaving large gaps between them of different shapes and sizes (Fig. 1Aii). These live morphological data are in good agreement with those obtained with scanning electron microscopy $[6,7]$.

Both arteriolar myocytes and venular pericytes were stained in situ with fluorescently la- 

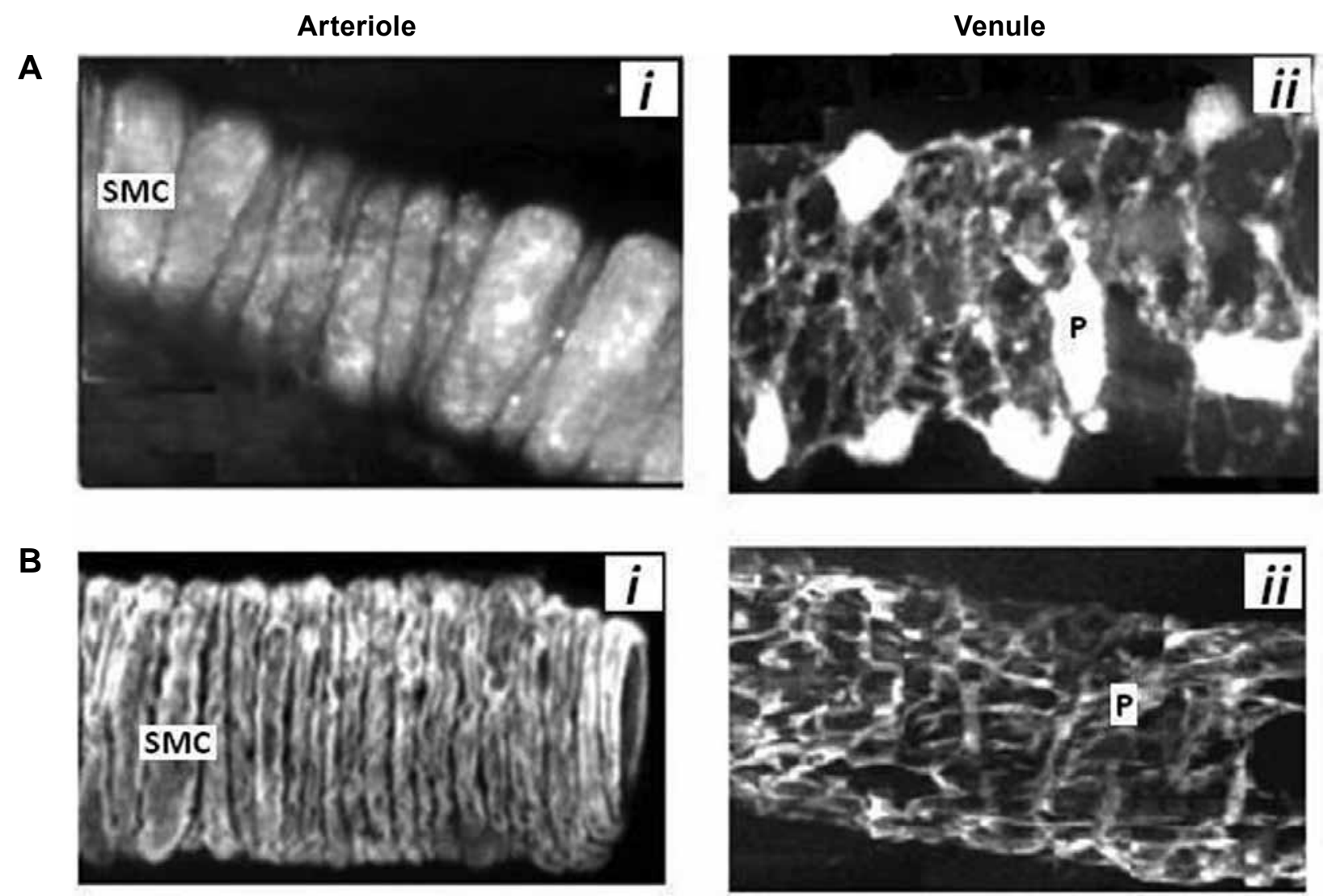

Fig. 1. Live images of ureteric arcade arteriole and arcade venule in situ. A: Images of fluo-4 loaded arcade arteriole and venule. B: Images of arcade arteriole and venule stained with phalloidin, SMC - smooth muscle cells; $P$ - pericytes

belled phalloidin in order to detect $\alpha$-actin filaments in the cells. Our data are in agreement with previous observations of Nehls and Drenckhahn [8]. Both myocytes and pericytes of arcade arterioles and venules were stained positively for $\alpha$-actin (Fig. 1Bi, ii), suggesting both media cells in these microvessels are contractile. The next we characterized $\mathrm{Ca}^{2+}$ signalling in myocytes and pericytes and related it to contraction in arterioles and venules, respectively.

\section{3. $\mathrm{Ca}^{2+}$ responses of arteriolar myocytes and venular pericytes to caffeine, phenylephrine and endothelin-1}

\subsection{Effects of caffeine}

$\mathrm{Ca}^{2+}$ release from the sarcoplasmic reticulum (SR), mediated by ryanodine receptors (RyRs) channels, can appear as $\mathrm{Ca}^{2+}$ sparks or waves and was shown to play a key role in control of vascular tone in small resistance arteries [9]. Caffeine is a known activator of $\mathrm{Ca}^{2+}$-induced $\mathrm{Ca}^{2+}$ release (CICR) from the SR mediated by RyRs channels. By using caffeine we aimed to answer the question whether myocytes of arcade arterioles and pericytes of arcade venules posses functional RyRs. Caffeine (1-2 $\mathrm{mM}$ ) induced $\mathrm{Ca}^{2+}$ oscillations in arteriolar myocytes, which showed variable amplitudes and spatial spread but had no effect even in high concentrations $(20 \mathrm{mM})$ on $\mathrm{Ca}^{2+}$ signalling in venular pericytes (Fig. 2Aii). These data demonstrate the presence of functional RyRs channels in myocytes of arcade arterioles, where they can be involved in control of local and global $\mathrm{Ca}^{2+}$ signalling but not in pericytes of arcade venules.

\subsection{Effects of phenylephrine}

The venous vessels have been reported to have no sympathetic nerve supply and show no change in diameter when the sympathetic supply to the muscle is activated [10].

We have used a non-hydrolysable analogue of noradrenalin, phenylephrine (PE) to investigate responsiveness of arteriolar myocytes and venular pericytes to topical application of catecholamine. In myocytes of arcade arterioles as we reported before [2] PE (5-10 $\mu \mathrm{M})$ induced asynchronous $\mathrm{Ca}^{2+}$ 
A
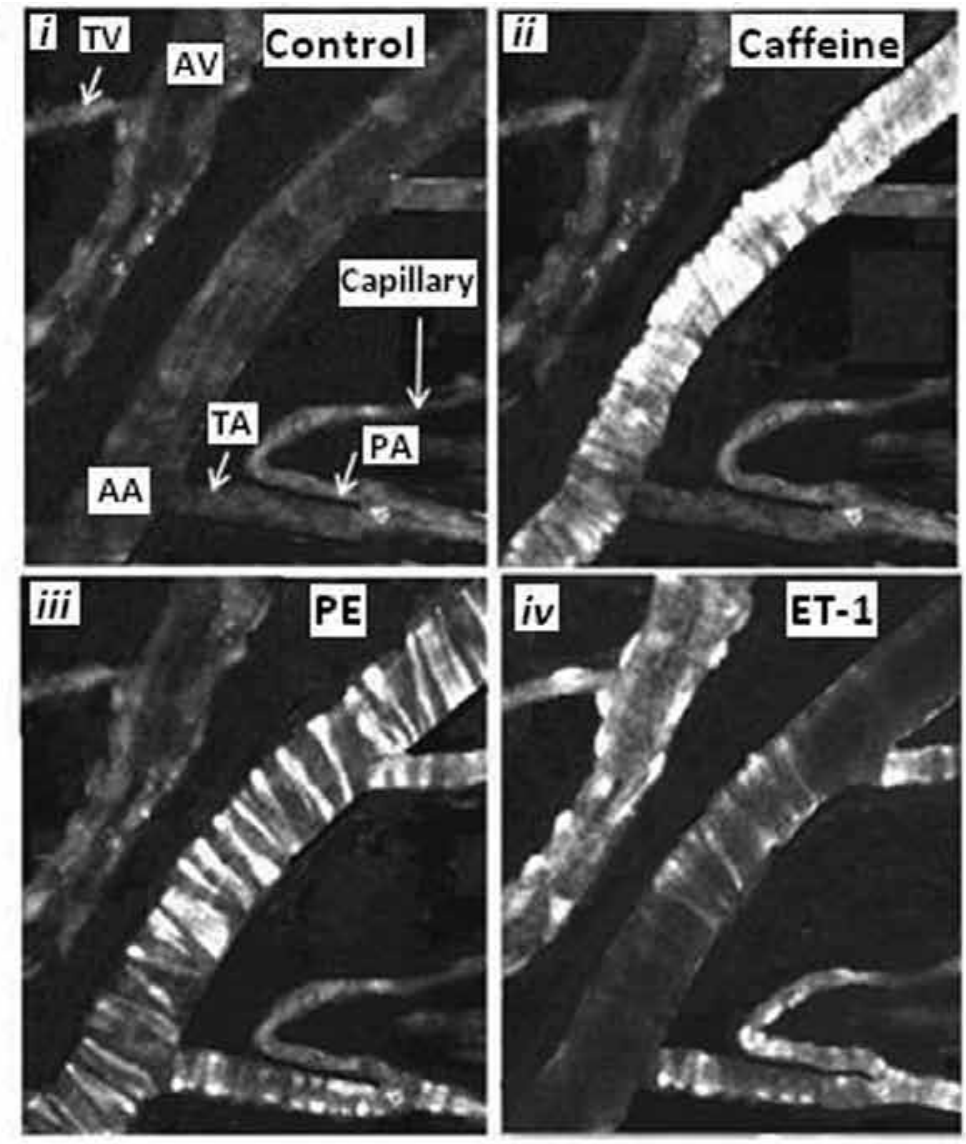

B

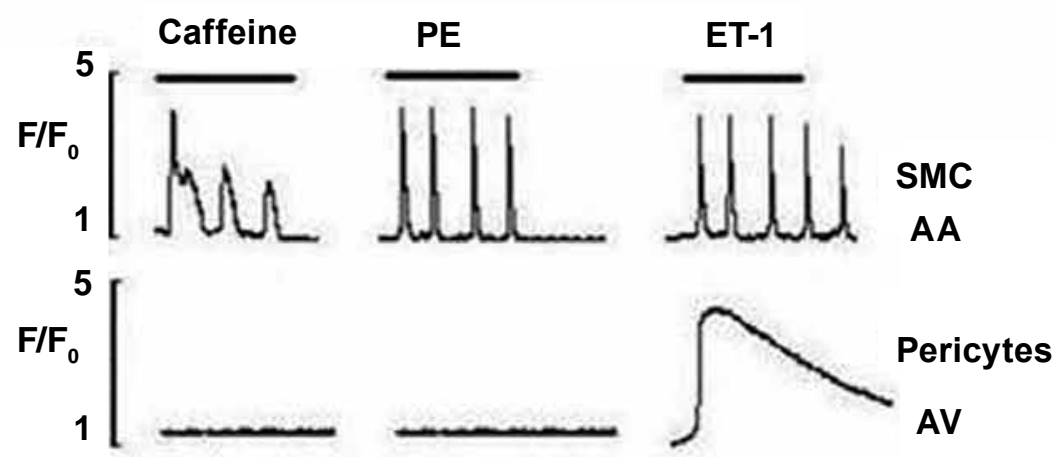

Fig. 2. Effects of caffeine, phenylephrine and endothelin-1 on $\mathrm{Ca}^{2+}$ responses of ureteric microvascular network in situ. A: Images of ureteric microvascular network in situ showing $\mathrm{Ca}^{2+}$ responses of myocytes of arcade arteriole (AA) and pericytes of arcade venules $(A V)$ to $5 \mathrm{mM}$ caffeine (ii), $5 \mu M$ phenylephrine (PE, iii), and $5 \mathrm{nM}$ endothilin-1 (ET-1, iv). B: Graph showing $\mathrm{Ca}^{2+}$ transients induced by caffeine $(2 \mathrm{mM}), P E(5 \mu M)$ and ET-1 (5 nM) in myocytes of $A A$ and pericytes of $A V$. Note that caffeine and PE produced $\mathrm{Ca}^{2+}$ oscillations in myocytes of $A A$ but had no effect on pericytes of $A V$. ET-1 induced $C a^{2+}$ oscillations in myocytes of $A A$ and long lasting $\mathrm{Ca}^{2+}$ transient in pericytes of $A V$. TV - transverse venules, TA - transverse arterioles, PA - precapillary arterioles 
Control

A

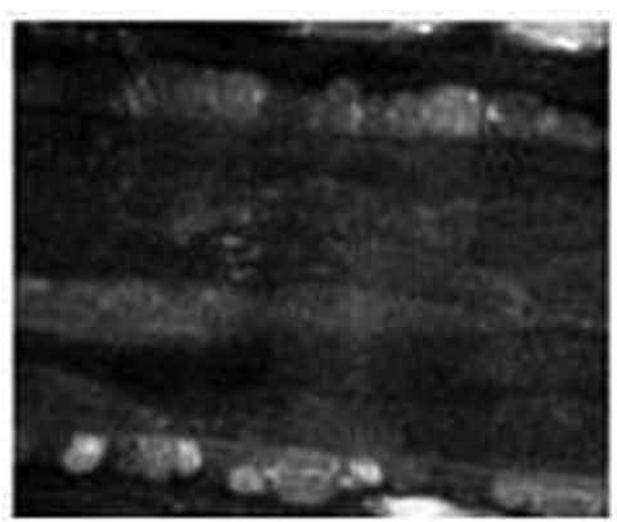

B

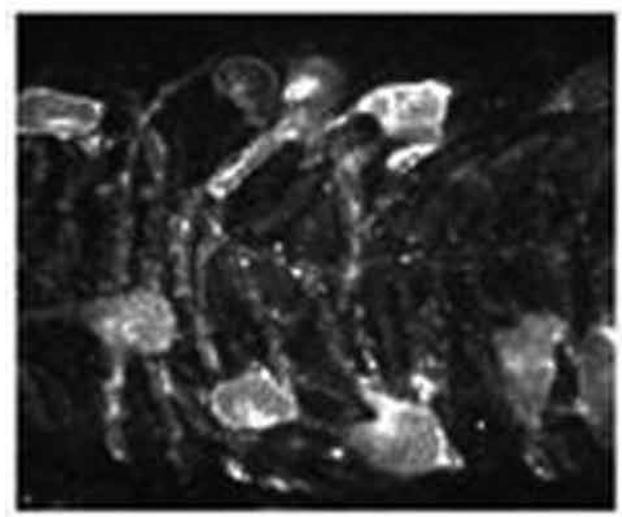

ET-1
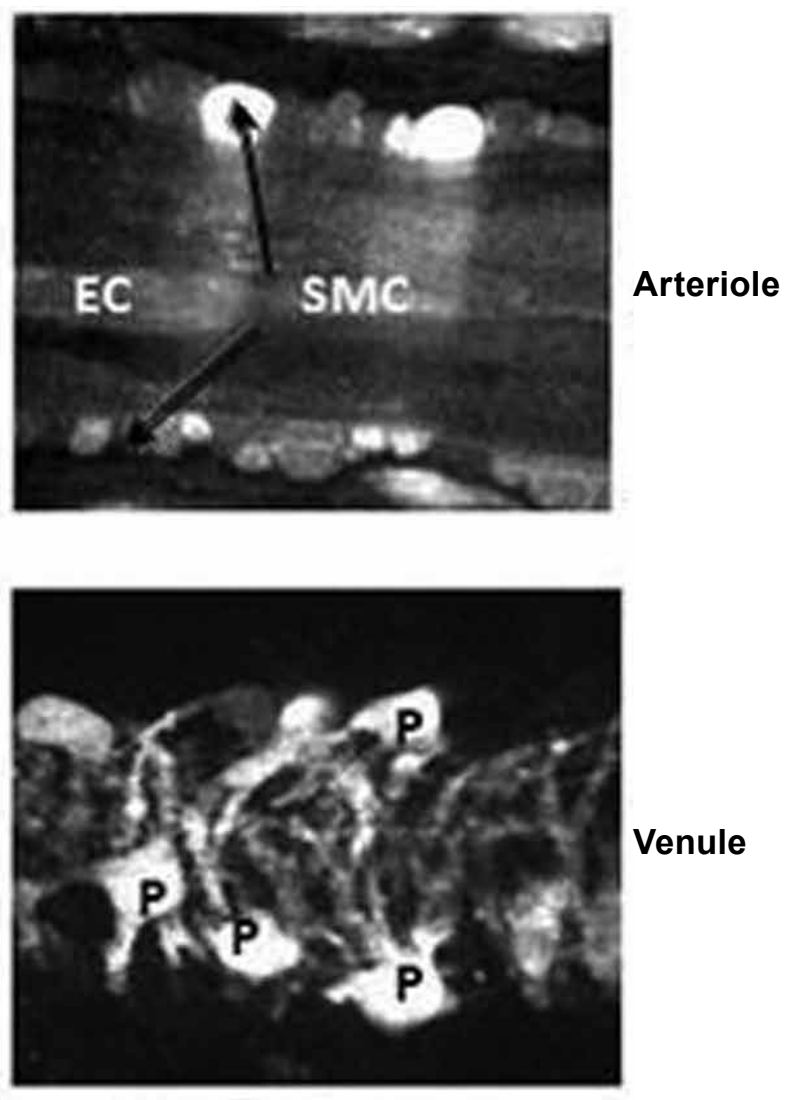

$20 \mu \mathrm{m}$

Fig. 3. Effects endothelin-1 on $\mathrm{Ca}^{2+}$ transients and contractility of myocytes of arcade arteriole and pericytes of arcade venules in situ. Note that asynchronous $\mathrm{Ca}^{2+}$ oscillations in myocytes (SMC) are associated with the regional vasomotion while the long lasting $\mathrm{Ca}^{2+}$ transient in pericytes $(P)$ is accompanied by strong venoconstriction. EC - endothelial cells

oscillations, which appeared as propagating $\mathrm{Ca}^{2+}$ waves (Fig. 2Aiii and 2B). Pericytes of the arcade venules were totally immune to PE (Fig. 2Aiii and 2B), which agrees with the in vivo studies [10].

\subsection{Effects of endothelin-1}

We have studied the effects of endothelin-1 (ET-1), a highly potent endothelium-derived vasoconstrictor on $\mathrm{Ca}^{2+}$ signals and contractility of arteriolar myocytes and venular pericytes. In myocytes of arcade arteriole ET-1 (5 nM) induced asynchronous $\mathrm{Ca}^{2+}$ oscillations, appeared as phasic propagating $\mathrm{Ca}^{2+}$ waves and accompanied by vasomotion, similar to those induced by PE (Fig. 2Aiv, 2B). Pericytes also strongly responded to ET-1 with the large increase in intracellular $\mathrm{Ca}^{2+}$, which appeared as a long lasting $\mathrm{Ca}^{2+}$ transient (Fig. 2Aiv and $2 \mathrm{~B}$ ). This steady state rise of intracellular $\mathrm{Ca}^{2+}$ produced strong venocosntriction induced by contraction of the pericytes' processes (Fig. 3B). Our data demonstrate distinct mechanisms, controlling $\mathrm{Ca}^{2+}$ signalling in myocytes and pericytes induced by the same agonist.

The application of $\mathrm{Ca}^{2+}$-imaging technology allowed us to demonstrate distinct mechanisms controlling $\mathrm{Ca}^{2+}$ signalling in myocytes and pericytes of arcade arterioles and venules, respectively. The highly dynamic responses evoked in smooth muscle cells by ET-1, for example, suggest that $\mathrm{Ca}^{2+}$ waves-like oscillations in myocytes control phasic contractile responses in arterioles but long lasting $\mathrm{Ca}^{2+}$ transient in pericytes control tonic contractile responses in venules. The future studies are needed to investigate the mechanisms controlling $\mathrm{Ca}^{2+}$ signalling and contractile activity in myocytes and pericytes. 


\section{Acknowledgements}

This work was supported by British Heart Foundation PG/12/62/29823.

\section{УВИДЕТЬ - ПОВЕРИТЬ! КОНФОКАЛЬНАЯ МИКРОСКОПИЯ МИКРОСОСУДОВ IN SITU: МОРФОЛОГИЯ, $\mathrm{Ca}^{2+}$ СИГНАЛИЗАЦИЯ И ТОНУС}

Т. Бурдыга, Л. Борисова

Отдел клеточной и молекулярной физиологии, Институт трансляционной медицины, Ливерпульский университет, Великобритания

Двух- и трехмерная конфокальная микроскопия позволяет получить изображения микрососудов в мочеточнике in situ с использованием флуоресцентного $\mathrm{Ca}^{2+}$-чувствительного зонда Fluo-4. Этот метод позволил нам продемонстрировать отчетливую морфологию, $\mathrm{Ca}^{2+}$ сигнализацию и сократительную активность миоцитов аркадных артериол и перицитов аркадных венул. В миоцитах и перицитах $\mathrm{Ca}^{2+}$ сигналы возникают исключительно за счет освобождения $\mathrm{Ca}^{2+}$ из саркоплазматического ретикулума посредством инозитол 1,4,5-трифосфатчувствительных рецепторов. В отличие от миоцитов $\mathrm{Ca}^{2+}$ транзиенты в перицитах менее осциллирующие и более продолжительные. Полученные данные предполагают наличие различных механизмов, контролирующих локальный кровоток в прекапиллярных артериолах и посткапиллярных венулах.

К л ю че вы е с лова: $\mathrm{Ca}^{2+}$ сигнализация, миоциты, перициты, микрососудистые сети, конфокальная микроскопия.

\section{ПОБАЧИТИ - ПОВІРИТИ! \\ КОНФОКАЛЬНА МІКРОСКОПІЯ \\ МІКРОСУДИН IN SITU: \\ МОРФОЛОГІЯ, $\mathrm{Ca}^{2+}$ СИГНАЛІЗАЦІЯ І ТОНУС}

\section{Т. Бурдига, Л. Борисова}

Відділ клітинної та молекулярної фізіології, Інститут трансляційної медицини,

Ліверпульський університет, Велика Британія

Дво- та тривимірна конфокальна мікроскопія дозволяє одержати зображення мікросудин в сечоводі in situ із використанням флуоресцентного $\mathrm{Ca}^{2+}$ чутливого зонда Fluo-4. Цей метод дозволив нам продемонструвати вираз- ну морфологію, $\mathrm{Ca}^{2+}$ сигналізацію і скоротливу активність міоцитів аркадних артеріол і перицитів аркадних венул. У міоцитах і перицитах $\mathrm{Ca}^{2+}$-сигнали виникають виключно за рахунок звільнення із саркоплазматичного ретикулума через інозитол 1,4,5-трифосфатчутливих рецептори. На відміну від міоцитів $\mathrm{Ca}^{2+}$ транзієнти в перицитах менш мінливі i э тривалішими. Одержані дані передбачають наявність різних механізмів, які контролюють локальний кровотік в прекапілярних артеріолах і посткапілярних венулах.

К л юч о в і с лов а: $\mathrm{Ca}^{2+}$ сигналізація, міоцити, перицити, мікросудинні сітки, конфокальна мікроскопія.

1. Burdyga T., Shmygol A., Eisner D. A., Wray $S$. // Cell Calcium. - 2003. - 34. - P. 27-33.

2. Borisova L., Wray S., Eisner D. A., Burdyga T. // Circ. Res. - 2009. - 105. - P. 803-810.

3. Perez J. F., Sanderson M. J. // J. Gen. Physiol. 2005. - 125. - P. 555-567.

4. Grynkiewicz G., Poenie M., Tsien R. Y. // J. Biol. Chem. - 1985. - 260. - P. 3440-3450.

5. De Backer D., Ospina-Tascon G., Salgado D.et al. // Intensive Care Med. - 2010. - 36. P. 1813-1825.

6. Fujiwara T., Tenkova T. I., Kondo M. // Anat. Rec., -1999. - 254. - P. 261-268.

7. Higuchi K., Hashizume H., Aizawa Y., Ushiki T. // Arch. Histol. Cytol. - 2000. - 63. - P. 115126.

8. Nehls V., Drenckhahn D. // J. Cell Biol. 1991. - 113. - P. 147-154.

9. Nelson M. T., Cheng H., Rubart M. et al. // Science. - 1995. - 270, N 5236. - P. 633-637.

10. Marshall J. M. // J. Physiol. - 1982. - 332. P. 169-186. 